\title{
ANALISIS TINGKAT KESEHATAN BANK \\ MENGGUNAKAN METODE CAMEL \\ DI PT PANIN DUBAI SYARIAH BANK PERIODE 2016-2020
}

\author{
Taufiq Ridwan Murtadho \\ STIE Tridharma \\ taufigridwan10@gmail.com
}

\author{
Rizky Ridwansyah \\ Perbankan Syariah, Universitas Al Ma'Soem \\ rizkyridwansyah33@gmail.com
}

\begin{abstract}
Along with the era, sharia banking is now soaring. With a system that implements revenue sharing and free from maisyir elements. So the community began to switch to keep the money and conduct other transactions at sharia banks. Because of the increasing number of Sharia banks, every bank is required to be able to maintain the level of health of the bank. Because this becomes the foundation of whether the bank is able or not to manage funds from customers and this becomes the main foundation of stakeholder trust. In the process of assessing the health of the bank there are several provisions that have been set in writing by Bank Indonesia, so that anyone can easily analyze, one of them by using camel method. Because the assessment of the bank's health level becomes a benchmark to evaluate the management of the bank. The purpose of this study is to analyze the level of health of banks using camel method in PT. Bank Panin Dubai Syariah period 2016-2019, the overall results of the evaluation in general performance and health in fairly healthy condition.
\end{abstract}

Keywords: Health, Bank, CAMEL

\begin{abstract}
ABSTRAK
Seiring berkemabangnya jaman, perbankan syariah kini semkain melesat. Dengan sistem yang menerapkan bagi hasil serta terbebas dari unsur maisyir. Maka masyarakat mulai beralih untuk menyimpan uangnya dan melalukan transaksi lainnya pada bank syariah. Karena semakin banyaknya bank syariah maka setiap bank dituntut untuk dapat mempertahankan tingkat kesehatan bank. Karena hal ini menjadi pondasi apakah bank mampu atau tidak untuk mengelola dana dari nasabah serta hal ini menjadi landasan utama kepercayaan stakeholder. Dalam proses penilaian kesehatan bank terdapat beberapa ketentuan yang sudah diatur secara tertulis oleh Bank Indonesia, sehingga siapapun dapat dengan mudah menganalisis, salah satunya dengan metode CAMEL. Karena penilaian tingkat kesehatan bank menjadi tolak ukur untuk mengevaluasi pengelolaan bank. Tujuan penelitian ini ialah analisis tingkat stabilitas bank dengan menggunakan metode CAMEL pada PT. Bank Panin Dubai Syariah periode 2016-2019, keseluruhan dari hasil evaluasi secara umum kinerja dan kesehatan dalam kondisi cukup sehat.
\end{abstract}

Kata Kunci : Kesehatan, Bank, CAMEL 


\section{PENDAHULUAN}

Jaman milenial semakin berkembang, sektor-sektor seperti pariwisata, perindustrian, perdagangan dan lain-lain saling berkompetensi untuk menunjukkan eksistensinya, tidak terkecuali dari sektor pebankan syariah yang dinilai menjadi salah satu pendongkrak dalam perputaran kegiatan perekonomian di masyarakat. Sejalan dengan Indonesia yang mayoritas masyarakatnya beragama muslim, kesempatan industri perbankan syariah menjadi lebih dinamis untuk mengembangkan usahanya. Selain alasan di atas, kemampuan bertahan terhadap krisis moneter tahun 1998 dan prinsip syariah yang menjadi landasan dalam setiap pengaplikasiannya menjadi daya tarik tersendiri untuk menarik minat para nasabah, pemegang saham, dan investor untuk menyimpan dana di bank syariah. Prinsip yang paling menjadi pusat perhatian adalah tidak adanya konsep bunga dan penerapan konsep kemitraan atau kerjasama dengan bagi hasil sebagai prinsip utamanya.

Industri perbankan syariah merupakan sektor yang mengedepankan tingkat kepercayaan masyarakat. Maka dari itu, penilaian kinerja suatu bank untuk mengetahui tingkat kesehatannya penting untuk dilakukan, baik oleh pihak ketiga, manajemen, pemerintah, pemegang saham, ataupun pihak lainnya. Dalam penilaian kinerja tersebut, pihak yang bersangkutan dapat meilihatnya dalam laporan keuangan yang biasanya telah dipublikasikan oleh Otoritas Jasa Keuangan maupun pihak bank itu sendiri.(Azwa \&
Afriani, 2016). Laporan keuangan disajikan untuk memberikan informasi mengenai berbagai jenis serta jumlah aktiva, modal, pendapatan, jumlah biaya serta menyangkut pelaporan operasional perusahaan dalam waktu tertentu. Karena laporan keuangan tidak hanya di konsumsi oleh internal perusahaan namun juga dibutuhkan oleh pihak eksternal terkait, sehingga dapat menilai kinerja dan prospek masa depan perusahaan (Kasmir, 2013).

Laporan keuangan juga dapat menggamabarkan tingkat kesehatan bank dari berbagai segi. Penilaian kesehatan bank berlandaskan pada berbagai risiko yang di hadapi dan memiliki dampak terhadap kinerja bank secara universal. Hal tersebut dilaksanakan melalui identifikasi faktor internal maupun eksternal yang mampu meningkatkan risiko bank pada saat ini maupun masa mendatang. Oleh sebab itu manajemen dapat mengidentifikasi akar permasalahan bank secara tepat waktu dan segera melakukan tindakan preventif dan korektif secara efektif dan efisien (Kusumawardani, 2014). Karena kondisi bank mencirikan kemampuan bank untuk menjalankan aktivitas perbankan dengan cara biasa serta dapat memenuhi kewajibannya sesuai dengan aturan yang berlaku (Sari, 2019).

Dengan pembesaran kompleksitas bisnis dan profil risiko, bank perlu menentukan apa maslahnya yang meungkin timbul sebagai akibat dari operasi bank. Sarana dalam menetapkan strategi usaha untuk masa depan yaitu mengacu pada hasil akhir kodnisi bank tersebut, di sisi 
lain bagi Bank Indonesia sebagai landasam dalam menerapkan strategi pengawasan. Tingkat kesehatan bank ialah hasil dalam penilaian kualitatif mengenai tingkat keandalan bank berkualitas tinggi dalam berbagai aspek apa yang mempengaruhi kondisi atau kinerja perusahaan melalui faktor-faktor meliputi modal. Kualitas aset, manajeemn, profitabilitas, likuiditas, dan sensitivitas terhadap risiko pasar, faktor ini dikenal dengan analissi CAMEL (Syahputra \& Saragih, 2016).

Beranjak dari fenomena yang telah dipaparkan diatas, penelitian ini akan difokuskan menganalisis stabilitas bank dengan menggunakan metode CAMEL. Secara keseluruhan, penulisan jurnal dengan pendekatan deskriptif dan kuantitaif dan metode kajian literature pustaka atau library research. Data yang dituangkan dalam penulisan jurnal ini bersumber dari data sekuner berupa laporan keuangan dari website resmi.

\section{Metodologi}

Metode pada artikel ini menggunakan analisis laporan keuangan dengan menggunakan CAMEL. Data yang yang terkumpul diamati secara tergambar. Kemudian, data yang terkumpul dihitung menggunakan rumus yang ditentukan sesuai dengan pengoprasian variabel. Langkah penilaain tingkat kesehatan setiap faktor dan komponen bank adalah dengan mengumpulkan data terkait variabel yang diteliti dari laporan keuangan perusahaan, kemudian menganalisis dan memeringkat masing-masing variabel.

\section{HASIL DAN PEMBAHASAN}

\section{Analisis Capital (Permodalan)}

Permodalan pada bank di ukur menggunakan Capital Adequacy Ratio (CAR). CAR ialah alat ukur kinerja bank digunakan mengenai kecukupan dalam modal yang mendukung aset atau menimbulkan risiko. Rasio ini digunakan untuk menahan kemungkinan kerugian. Jika rasio ini tinggi maka menggambarkan bank dalam keadaan baik mampu menganggung risiko kredit dari aset produktif tertimbang menurut risiko (Rahmani, 2017).

Permodalan untuk bank sebagai perusahaan umumnya selain menjadi sumber utama pembiayaan untuk operasinya, bertindak sebagai penyangga terhadap kemungkinan terjadinya kerugian. Modal yang ada pada bank pada prinsipnya harus cukup untuk menutupi risiko bisnis yang di hadapi. Sebagai indikator dalam modal CAR harus berada pada nominal yang telah ditentukan oleh BI yaitu 8\% dari total aset. Maka jika CAR menurun menggambarkan kondisi modal bank sedang melemah (Fiscal \& Lusiana, 2014). Berikut data disajikan:

Tabel 1 Data Capital Adequacy Ratio (CAR)

\begin{tabular}{|c|r|c|}
\hline Periode & $\begin{array}{r}\text { Data } \\
\text { Variabel }\end{array}$ & Presentase \\
\hline 2016 & 18,17 & - \\
\hline 2017 & 11,51 & $-6,66$ \\
\hline 2018 & 23,15 & 11,64 \\
\hline 2019 & 14,46 & $-8,69$ \\
\hline
\end{tabular}

Data yang di peroleh mulai dari tahun 2016 sampai dengan 2019 masing-masing sebesar $\quad 18,17 \% \quad 11,51 \% \quad 23,15 \% \quad 14,46 \%$. 
Sesuai kriteria yang telah ditetapkan rasio kecukupan modal harsu di jaga dalam batas aman minimum $8 \%$ sedangkan yang dimiliki lebih besar dari masing-masing berada pada interval tertinggi karena $\geq$ $12 \%$ yang berarti termasuk dalam kategori sangat sehat, hanya pada tahun 2017 saja nilai CAR berada pada kategori sehat karena berada pada interval kedua.

\section{Analisis Kualitas Aset}

Pada penilaian ini didasarkan pada kualitas aset produktif yang dimiiki bank merupkan rasio pendapatan aset yang diklasifikasikan terhadap aset pendapatan. Untuk mengukur tingkat kemungkinan pemulihan investasi (Kasmir, 2017). KAP merupakan perbandingan aset produktif yang dikelompokkan dengan aktiva produktif. Aset ini termasuk pada aktiva yang baik yang tidak mengandung potensi kerugian digolongkan menjadi empat yaitu aset dalam perhatian khusus, kurang lancar, diragukan dan tidak menguntungkan (Debora et al., 2015).

Aset produktif menjadi sumber pendapatan bank, karena sumer ini memiliki risiko yang besar. Namun potensi risiko ini dapat dicegah dengan membentuk penyisihan penghapusan aktiva produktif (PPAP) berupa cadangan umum dan khusu dengan begitu dapat merecovery kemungkinan kerugian (Taswan, 2005). Terdapat beberapa komponen untuk menilai KAP yaitu dperbandingan antara Aktiva Produktif Yang Diklasifikasikan (APYD) dan jumlah Aktiva Produktif (AP) (Susila, 2017). Berikut data KAP dalam rentang waktu empat tahun.
Tabel 2 Data Kualitas Aktiva Produktif

\begin{tabular}{|c|c|c|}
\hline Periode & $\begin{array}{c}\text { Kualitas } \\
\text { Aktiva } \\
\text { Produktif }\end{array}$ & Presentase \\
\hline 2016 & 1,76 & - \\
\hline 2017 & 9,77 & 8,01 \\
\hline 2018 & 3,99 & $-5,78$ \\
\hline 2019 & 2,76 & $-1,23$ \\
\hline
\end{tabular}

Rasio KAP yang dicapai sebesar 1,77\% 9,77\% 3,99\% 2,76\%. Sesuai ketentuan yang telah ditetapkan oleh Bank Indonesia rasio KAP harus dijaga dalam batas aman minimal 3\%. Pada tabel disajikan di atas nilai KAP tahun 2016 berada pada kategori sehat karena $\leq 2 \%$, sedangkan pada tahun 2017 KAP berada pada kategori tidak sehat karena lebih dari 9\%, selanjutnya untuk tahun 2018 hingga 2019 berada pada kategori cukup sehat dengan pada nilai interval $3 \% \leq \mathrm{NPM} \geq 6 \%$.

\section{Analisis Manajemen}

Untuk menentukan sehat tidaknya suatu bank dinilai dari kualitas manajemennya. Oleh karean itu, manajemen bank memberikan perhatian yang cukup besar untuk menilai stabilitas bank. Penilaian manajemen ini menggunakan rasio Net Profit Margin (NPM). NPM adalah koefisien yang menghitung derajat kemampuan perusahaan untuk menghasilkan laba bersih pada tingkat penjualan tertentu. Dengan membandingkan net income dengan penjualan bersih (Safitri \& Mukaram, 2018).

Jika nilai NPM tinggi menggambarkan kinerja perusahaan baik, dengan begitu investor akan percaya untuk menanamkan 
modalnya. Rasio ini juga memberikan informasi mengenai jumlah laab bersih dari hasil penjualan. Jika rasio ini tinggi maka mencerminkan semakin baik perusahaan dalam mendapatkan laba (Bastian, 2006). Dengan begitu manajemen perusahaan harus dapat mengoptimalkan penjualan karen menjadi penentu sumber laba perusahaan. Unsur-unsur NPM yaitu laba kotor, laba operasi, laba bersih dan laba ditahan (Sigarlaki et al., 2014). Berikut data disajikan:

Tabel 3 Data Net Profit Margin (NPM)

\begin{tabular}{|c|c|c|}
\hline Periode & $\begin{array}{c}\text { Net Profit } \\
\text { Margin } \\
\text { (NPM) }\end{array}$ & Presentase \\
\hline 2016 & 71,07 & - \\
\hline 2017 & $-100,7$ & $-171,07$ \\
\hline 2018 & 72,84 & 173,91 \\
\hline 2019 & 71,14 & $-1,7$ \\
\hline
\end{tabular}

Rasio NPM yang dicapai mulai dari tahun 2016 sampai dengan 2019 masingmasing sebesar $71,07 \%-100,7 \%$ 72,84\% dan $71,14 \%$. Sesuai ketentuan yang telah ditetapkan oleh Bank Indonesia untuk peringkat rasio ini tahun 2016, 2018, dan 2019 termasuk dalam kategori cukup sehat karena berada pada interval 66\% $\leq \mathrm{NPM} \geq$ 81\%. Namun pada tahun 2017 nilai NPM termasuk dalam kategri tidak sehat karena mengalami penurunan yang cukup drastis hingga mencapai nilai $-100,7 \%$.

\section{Analisis Earning (Rentabilitas)}

Menurut Kasmir dalam penilaian unsur rentabilitas didasarkan pada dua macam yaitu menggunkann rasio ROA dan BOPO. ROA merupakan koefisien yang menunjukkan profitabilitas dari total aset yang digunakan dalam perusahaan, dan tingkat efisiensi manajemen dalam mengelola asetnya (Kasmir, 2017). Semakin tinggi rasionya maka semakin efisien penggunaan aset perusahaan (Astarani \& Siregar, 2016). Rasio ini menjadi penentu besarnya dividen yang akan di bagikan, jika ROA mengalami kenaikan yang tinggi setiap tahunnya maka dividen yang akan diterima akan meningkat. Maka performa perusahaan akan semakin baik (Magia \& Widayanti, 2012). Berikut data ROA disajikan:

Tabel 4 Data Return on Asset (ROA)

\begin{tabular}{|c|c|c|}
\hline Periode & ROA & Presentase \\
\hline 2016 & 0,37 & - \\
\hline 2017 & $-10,77$ & $-11,14$ \\
\hline 2018 & 0,26 & 11,03 \\
\hline 2019 & 0,25 & $-0,01$ \\
\hline
\end{tabular}

Rasio ROA yang dicapai mulai dari tahun 2016 sampai dengan 2019 masingmasing sebesar $0,37 \%-10,77 \%$ 0,26\% dan $0,25 \%$. Sesuai ketentuan yang telah ditetapkan oleh Bank Indonesia untuk peringkat ROA dalam kurun waktu empat tahun termasuk dalam kategori kurang ehat karena berada pada interval $0 \leq \mathrm{ROA}$ $\geq 0,05 \%$.

Biaya operasional meliputi biaya yang dikeluarkan bank untuk kegiatan usaha seperti biaya bunga, biaya tenaga kerja, biaya pemasaran dan biaya operasi lainnya. Sedang pendapatan operasional adalah pendapatan utama bank meliputi pendapatan bunga yang diperoleh dari 
penempatan dana berupa kredit dan pendapatan operasi lainnya (Sudarmawanti \& Pramono, 2017). Efisiensi dalam operasi bank untuk mengoptimalkan beban usaha pokok bank, menunjukkan apakah produknya tepat guna dan hasil guna. Maka efisiensi ini akan mempengaruhi kinerja suatu bank. Karena jika kinerja bank baik maka masyarakat akan tertarik untuk menyimpan dananya, dengan begitu profitabilitas yang diharapkan meningkat (Magia \& Widayanti, 2012). Berikut data BOPO disajikan.

Tabel 5 Data BOPO

\begin{tabular}{|c|c|c|}
\hline Periode & BOPO & Presentase \\
\hline 2016 & 96,17 & - \\
\hline 2017 & 217,40 & 121,23 \\
\hline 2018 & 99,57 & $-117,43$ \\
\hline 2019 & 97,74 & $-1,83$ \\
\hline
\end{tabular}

Rasio BOPO yang dicapai mulai dari tahun 2016 sampai dengan 2019 masingmasing sebesar 96,17\% 217,40\% 99,57\% dan $97,74 \%$. Sesuai ketentuan yang telah ditetapkan oleh Bank Indonesia untuk peringkat BOPO pada tahun 2016, 2018, dan 2019 termasuk dalam kategori kurang ehat karena berada pada interval $96 \% \leq$ BOPO $\geq 97 \%$. Sedangkan pada tahun 2017 berada pada kategori tidak sehat karena melebihi dari $97 \%$.

\section{Analisis Likuiditas}

Aspek likuiditas bank didasarkan pada keuangan bank dalam melunasi semua hutang terutama tabungan, giro dan deposito berjangka. Di ukur oleh rasio Loan to Deposito Ratio (LDR) ialah rasio antara total volume kredit yang diberikan bank dengan jumlah dana yang diperoleh dari berbagai sumber, semakin tinggi rasio tersebut maka semakin rendahnya likuiditasnya (Arniati, Rohana, 2018). Jika rasio LDR di bawah 78\% maka bank tersebut telah melebihi dana yang dihimpun. Pasalnya, dalam mengelola dana masyarakat bank dituntut untuk menjaga likuiditasnya agar bisa mendapat kepercayaan masyarakat (Septiani \& Lestari, 2016).

Apabila pertumbuhan pembiayaan lebih besar dari pertumbuhan jumlah dana yang dihimpun bank maka akan menimbulkan LDR meningakat. Akibatnya niali likuiditas menurun. Karena jumlah dana untuk pembiayaan menjadi besar. Untuk menghitung nilai LDR membagi jumlah pembiayaan di bagi dengan total dana yang diterima (Yuliani et al., 2015).

LDR merupakan pengukuran tradisional menunjukkan besarnya deposito berjangka, giro, tabungan dan yang lain yang digunakan sebagai pemenuhan permohonan pinjaman nasabah. Maka rasio ini menjadi alat ukur tinggi rendahnya likuiditas suatu bank. Maka bank harus dapat mempertahankan nilai rasio ini karena menggamabrkan tingkat likuid bank (Fitria \& Sari, 2012). Berikut data Loan to Deposito Ratio (LDR) sebagai berikut.

Tabel 6 Data Loan to Deposito Ratio (LDR)

\begin{tabular}{|c|c|c|}
\hline Periode & $\begin{array}{r}\text { Loan to } \\
\text { Deposito } \\
\text { Ratio (LDR) }\end{array}$ & Presentase \\
\hline 2016 & 91,99 & - \\
\hline 2017 & 86,95 & $-5,04$ \\
\hline 2018 & 88,82 & 1,87 \\
\hline
\end{tabular}




\begin{tabular}{|l|l|l|}
\hline 2019 & 96,23 & 7,41 \\
\hline
\end{tabular}

PT. Bank Panin Dubai Syariah, Tbk mulai dari tahun 2016 sampai dengan 2019 masing-masing sebesar 91,99\% 86,95\% $88,82 \%$ dan $96,23 \%$. Sesuai ketentuan yang telah ditetapkan oleh Bank Indonesia untuk peringkat LDR dalam kurun waktu empat tahun termasuk dalam kategori cukup sehat karena berada pada interval $85 \% \leq \mathrm{LDR} \geq 100 \%$.

Hasil penilaian terhadap analisis CAMEL mulai dari tahun 2016 hingga melalui tabel berikut:

Tabel 7

Hasil Evaluasi CAMEL PT. Panin Dubai Syariah, Tbk Periode 2016-2019

\begin{tabular}{|c|c|c|c|c|c|c|}
\hline Tahun & $\begin{array}{c}\text { Faktor } \\
\text { Penilaian }\end{array}$ & $\begin{array}{c}\text { Indikator } \\
\text { Kerja }\end{array}$ & $\begin{array}{c}\text { Nilai } \\
\text { Rasio (\%) }\end{array}$ & $\begin{array}{c}\text { Nilai } \\
\text { Kredit }\end{array}$ & $\begin{array}{c}\text { Bobot } \\
(\%)\end{array}$ & $\begin{array}{c}\text { Nilai } \\
\text { CAMEL }\end{array}$ \\
\hline \multirow{6}{*}{2016} & Permodalan & CAR & 18,17 & 100 & 25 & 25 \\
\hline & $\begin{array}{c}\text { Kualitas } \\
\text { Aktiva } \\
\text { Produktif }\end{array}$ & KAP & 1,76 & 92,6 & 30 & 27,78 \\
\hline & Management & NPM & 71,07 & 71,07 & 25 & 17,77 \\
\hline & \multirow[b]{2}{*}{ Earning } & ROA & 0,37 & 25 & 5 & 1,25 \\
\hline & & $\mathrm{BOPO}$ & 96,17 & 48 & 5 & 2,4 \\
\hline & Likuiditas & LDR & 91,99 & 100 & 10 & 10 \\
\hline \multicolumn{6}{|c|}{ Total Nilai CAMEL } & 84,19 \\
\hline \multirow{6}{*}{2017} & Permodalan & CAR & 11,51 & 100 & 25 & 25 \\
\hline & $\begin{array}{c}\text { Kualitas } \\
\text { Aktiva } \\
\text { Produktif }\end{array}$ & KAP & 9,77 & 39,2 & 30 & 11,76 \\
\hline & Management & NPM & $-100,7$ & $-100,7$ & 25 & $-25,18$ \\
\hline & & ROA & $-10,77$ & -718 & 5 & $-35,9$ \\
\hline & Earning & $\mathrm{BOPO}$ & 217,4 & 0 & 5 & 0 \\
\hline & Likuiditas & LDR & 86,95 & 100 & 10 & 10 \\
\hline \multicolumn{6}{|c|}{ Total Nilai CAMEL } & $-14,32$ \\
\hline \multirow{4}{*}{2018} & Permodalan & CAR & 23,15 & 100 & 25 & 25 \\
\hline & $\begin{array}{c}\text { Kualitas } \\
\text { Aktiva } \\
\text { Produktif }\end{array}$ & KAP & 3,99 & 77,73 & 30 & 23,319 \\
\hline & Management & NPM & 72,84 & 72,84 & 25 & 18,21 \\
\hline & Earning & ROA & 0,26 & 17,33 & 5 & 0,8665 \\
\hline
\end{tabular}




\begin{tabular}{|c|c|c|c|c|c|c|}
\hline & & BOPO & 99,57 & 5,38 & 5 & 0,269 \\
\hline & Likuiditas & LDR & 88,82 & 100 & 10 & 10 \\
\hline \multicolumn{6}{|c|}{ Total Nilai CAMEL } & 77,66 \\
\hline \multirow{6}{*}{2019} & Permodalan & CAR & 14,46 & 100 & 25 & 25 \\
\hline & $\begin{array}{c}\text { Kualitas } \\
\text { Aktiva } \\
\text { Produktif }\end{array}$ & KAP & 2,76 & 85,93 & 30 & 25,779 \\
\hline & Management & NPM & 71,14 & 71,14 & 25 & 17,79 \\
\hline & \multirow[b]{2}{*}{ Earning } & ROA & 0,25 & 16,66 & 5 & 0,833 \\
\hline & & $\mathrm{BOPO}$ & 99,74 & 3,25 & 5 & 0,1625 \\
\hline & Likuiditas & LDR & 96,23 & 100 & 10 & 10 \\
\hline \multicolumn{6}{|c|}{ Total Nilai CAMEL } & 79,56 \\
\hline
\end{tabular}

Merujuk pada tabel diatas menunjukkan analisis CAMEL secara keseluruhan. Sesuai ketentuan yang telah ditetapkan oleh Bank Indonesia mengenai penilaian kesehatan bank, tahun 2016 termasuk dalam kategori sehat dengan nilai 84,19. Namun pada tahun 2017 berada pada kategori tidak sehat karena mengalami penurunan dengan nilai CAMEL -14,32 hal ini terjadi karena management mengalami minus dalam operasionya. Tetapi menginjak tahun 2018 bank mengalami pertumbuhan kembali dan berada pada posisi cukup sehat dengan nilai 77,66 dan terakhir pada tahun 2019 tingkat kesehatan bank berada pada kategori cukup sehat dengan nilai 79,56.

\section{SIMPULAN}

Mengacu pada hasil kajian dan pembahasan masing-masing faktor CAMEL secara umum dapat disimpulkan bahwa PT. Bank Panin Dubai Syariah Tbk, dalam kondisi cukup sehat. Hal ini dikarenakan pengelolaan dana belum dikelola secara maksimal, sehingga terjadi penurunan secara drastis dalam pengelolaan laba perusahaan dan beban operasi yang sangat tinggi menjadi tidak seimbang dengan faktor yang lain termasuk dengan likuiditas sehingga pada tahun 2017 nilai CAMEL minus. Implikasinya pihak manajemen harus lebih peka dalam memprediksi kinerja bank di masa yang akan datang, mengingat tingkat persaingan semakin ketat, maka dalam proses pemberian pembiayaan, pengelolaan modal serta faktor lainnya harus lebih dipertimbangkan dan untuk memulihkan pada kondisi bank dalam keadaan sehat diperlukannya strategi yang diterapkan oleh tim manajemen. 


\section{DAFTAR PUSTAKA}

Arniati, Rohana, S. (2018). Pengaruh Loan to Deposit Ratio terhadap Non Performing Loan. Jurnal Ilmiah: Jurmal Ilmu Manajemen, 6(1), 77-82. https://journals. synthesispublication.org/index.php/Ilman/article/view/8

Astarani, J., \& Siregar, J. S. (2016). Pengaruh Return On Asset (ROA) terhadap Nilai Perusahaan Dengan Pengungkapan Corporate Social Responsibility (CSR) sebagai Variabel Pemoderasi pada Perusahaan Manufaktur yang Terdaftar di Bursa Efek Indonesia (BEI). Jurnal Audit Dan Akuntansi, 5(1), 49-76.

Azwa, S., \& Afriani, S. (2016). Analisis Kinerja Keuangan Pada Pt. Bank Pembiayaan Rakyat Syariah (Bprs) Muamalat Harkat Sukaraja. EKOMBIS REVIEW: Jurnal Ilmiah Ekonomi Dan Bisnis, 4(2), 156-168. https://doi.org/10.37676/ekombis. v4i2.281

Bastian, I. S. (2006). Akuntansi Perbankan Edisi Pertama. Salemba Empat.

Debora, N., Saerang, I., \& Untu, V . (2015). Analisis Perbandingan Kinerja Keuangan dengan Menggunakan Metode Camel Pada Pt. Bank Jateng Dan Pt. Bank Dki. Jurnal EMBA: Jurnal Riset ...,3(1), 1117-1128. https://ejournal.unsrat.ac.id/index. php/emba/article/view/7926

Fiscal, Y., \& Lusiana, L. (2014). Pengaruh Capital Adequacy Ratio (Car), Loan to Deposit Ratio (LDR), Biaya Operasional dan Pendapatan Operasional (BOPO) terhadap Profitabilitas BPR ( Studi Kasus pada BPR di Provinsi Lampung Tahun 2010 2012 ). Jurnal Akuntansi Dan Keuangan, 5(2), 127-157.

Fitria, N., \& Sari, R. L. (2012). Analisis Kebijakan Pemberian Kredit dan Pengaruh Non Performing Loan terhadap Loan to Deposit Ratio pada PT. Bank Rakyat Indonesia (persero), tbk Cabang Rrantau, Aceh Tamiang. ( Periode 2007-2011). Jurnal Ekonomi Dan Keuangan, 1(1), 88-101. https://doi.org/10.1094/PDIS-08-161092-PDN

Kasmir. (2013). Analisis Laporan Keuangan. PT Raja Grafindo Persada.

Kasmir. (2017). Analisa Laporan Keuangan Edisi Satu sampai Sepuluh. PT Raja Grafindo Persada.

Kusumawardani, A. (2014). Analisis Perbandingan Tingkat Kesehatan Bank dengan Menggunakan Metode Camels dan RGEC pada PT. Bank xxx Periode 20082011. Jurnal Ekonomi Bisnis, 19(3), 16-22.

Magia, C. A., \& Widayanti, R. (2012). Pengaruh Return on Asset, Return on Equity dan Debt to Equity Ratio terhadap Harga Saham. Jurnal Ilmiah Manajemen Bisnis, 12(2), 55-62.

Rahmani, N. A. B. (2017). Analisis Pengaruh Capital Adequacy Ratio (CAR) dan Financing to Deposit Ratio (FDR) terhadap Return On Asset (ROA) dan Return 
On Equity (ROE) Pada Perusahaan Bank Umum Syariah di Indonesia. Human Falah, 4(2), 299-316.

Safitri, A. M., \& Mukaram, M. (2018). Pengaruh ROA, ROE, dan NPM Terhadap Pertumbuhan Laba Pada Perusahaan Sektor Industri Barang Konsumsi Yang Terdaftar di Bursa Efek Indonesia. Jurnal Riset Bisnis Dan Investasi, 4(1), 25. https://doi.org/10.35697/jrbi.v4i1.990

Sari, R. K. (2019). Analisis Kesehatan Bank Dengan Metode Camel (Studi Kasus : Pt. Bank Tabungan Negara, Tbk Periode 2011-2015). Monex: Journal Research Accounting Politeknik Tegal, 8(1), 208. https://doi.org/10.30591/monex.v8i1.1115

Septiani, R., \& Lestari, P. V. (2016). Pengaruh NPL dan LDR terhadap Profitabilitas Dengan CAR sebagai Variabel Mediasi pada PT BPR Pasarraya Kuta. E-Jurnal Manajemen Unud, 5(1), 293-324.

Sigarlaki, P., Karamoy, H., \& Elim, I. (2014). Analisis net Profit Margin pada Perusahaan Depot Air Minum di Lingkungan Kampus Universitas Sam Ratulangi. Jurnal $E M B A, 2(2), 1617-1625$.

Sudarmawanti, E., \& Pramono, J. (2017). Pengaruh CAR, NPL, BOPO, NIM dan LDR Terhadap ROA (Studi Kasus Pada Bank Perkreditan Rakyat di Salatiga yang terdaftar di Otoritas Jasa Keuangan tahun 2011 - 2015). Among Makarti, 10(19), $1-18$.

Susila, G. putu agus jana. (2017). Pengaruh Kualitas Aktiva Produktif, Capital Adequacy Ratio, Dan Loan To Deposit Ratio terhadap Profitabilitas Pada Lembaga Perkreditan Desa. Jurnal Ilmu Sosial Dan Humaniora, 6(2), 108-114.

Syahputra, R., \& Saragih, A. F. (2016). Analisis Tingkat Kesehatan Bank dengan Metode RBBR. Jurnal Administrasi Bisnis, 37(1), 37-45.

Taswan. (2005). Akuntansi Perbankan. UPP AMP YPKN.

Yuliani, K. P., Werastuti, D. N. S., \& Edy, S. (2015). Pengaruh Loan to Deposit Ratio ( LDR ), Non Performing Loan ( NPL ), Return on Asset ( ROA ) dan Opersional terhadap Pendapatan Operasional ( BOPO ) terhadap Capital Adequacy Ratio ( CAR ) ( Studi Pada Bank Umum Swasta Nasional ( BUSN ) Devisa ). E-Journal Ak S1 Universitas Pendidikan Ganesha, 3(1), 1-11. 